\title{
al Fikrah
}

Jurnal Studi Ilmu Pendidikan dan Keislaman

ISSN (Media Cetak) : 2620-4207 ISSN (Media Online) : 2620-4304

Volume 4, Nomor 1, Juni 2021

Terakreditasi Sinta Nomor: 200/M/KPT/2020

Diterbitkan Oleh : STAI Al-Hamidiyah Bangkalan

\section{MELACAK PEMBENTUKAN \\ PRINSIP-PRINSIP HIDUP KOMUNITAS BLATĒR \\ DAN JUSTIFIKASI DALAM AJARAN AGAMA ISLAM}

\author{
TRACKING THE ESTABLISHMENT \\ OF BLATËR COMMUNITY LIFE PRINCIPLES \\ AND JUSTIFICATION IN ISLAMIC RELIGIOUS TEACHINGS
}

\author{
Muniri, S.HI, M.HI ${ }^{1}$ \\ STAI Al-Hamidiyah Bangkalan \\ mc.azumy@gmail.com
}

\begin{abstract}
Abstrak:
Pada tahapan-tahapan pembentukan prinsip hidup komunitas Blatér, yang meliputi ketauhidan, hormat kepada Embho' (Ibu), hormat kepada ghuru (Guru), ajhegeh téngka (menjaga etika), dan ajhegeh harga diri. Lima prinsip hidup Blatér ini, dimapankan dalam berbagai kesempatan, utamanya dalam momentum remoh. Remoh menjadi momentum ideal dalam menyesuaikan diri antara Blatér satu dengan Blatér lainnya. Modal imitasi yang didapatkan dari lingkungan terdekat tentang kosakata dan kehidupan Blatér, melahirkan proses sugesti pengalaman kebelatêran kepada dirinya. Dari sugesti ini, berlanjut pada proses identifikasi diri dengan karakteristik Blatêr, hingga pada upaya menemukan figur penting yang dijadikan rujukan dalam sepak terjangnya di dunia kebelatêran. Adapun bahasan tentang lima prinsip hidup komunitas
\end{abstract}

${ }^{1}$ Dosen Tetap STAI AL-Hamidiyah Bangkalan 
Blatēr ditinjau dari ajaran agama Islam, ternyata hanya empat prinsip hidup, yaitu ketauhidan, hormat kepada Embho' (Ibu), hormat kepada ghuru (Guru), ajhegeh téngka (menjaga etika), yang ada justifikasinya dalam Al-Qur' an maupun Al-Hadits, sedangkan yang satu lagi; yaitu ajhegeh harga diri tidak ada justifikasinya dalam Al-Qur' an dan Al-Hadits.

Kata Kunci: Komunitas Blatér, interaksi sosial, Islam

\begin{abstract}
:
This article is the result of tracing the stages in the formation of the Blater community's principles of life, which include monotheism, respect for Embho' (Mother), respect for Ghuru (teacher), ajhegeh téngka (maintaining ethics), and ajhegeh harga diri (keep self-esteem). These five principles of Blatér's life have been established on various occasions, mainly in crumbling moments. Remoh is the ideal moment to adjust Blatér to Blatér. The imitation capital obtained from his immediate environment about Blatér's word and life creates a process of suggestion experience to him. From this suggestion, it continues with the process of identifying oneself with Blatēr's characteristics, the effort is to find important figures who are used as references in their activities in the world of keblatéran. As for the discussion of the five principles of life of the Blatêr community in terms of Islamic teachings, it turns out that there are only four principles of life, namely monotheism, respect for Embho' (Mother), respect for the Ghuru (Teacher), ajhegeh téngka (maintaining ethics), which is justified in Al-Qur'an and Al-Hadith, while the other one; namely ajhegeh harga diri keep self-esteem has no justification in the Al-Qur'an and Al-Hadith.
\end{abstract}

Keywords: Blatér Community, social interaction, Islam.

\title{
Pendahuluan
}

Komunitas sosial yang mapan seringkali memiliki pandangan hidup, yang berasal dari hasil refleksi kesejarahan eksistensinya. Tidak terkecuali komunitas Blatêr, yang menjadikan pandangan hidupnya mutlak sebagai pegangan, pedoman, arahan, petunjuk dan sebagai prinsip berpikirbertindak dalam interaksi sosialnya. Meskipun rumusan pandangan hidup terdapat paradok di dalamnya, tapi bagaimanapun itu merupakan hasil pergulatan eksistensial dari segala pengalaman dan pemaknaan atas hidup komunitas Blatēr sendiri. Justru dari paradoksalitas itu, menjadi penanda 
bahwa prinsip seseorang/komunitas dengan oranglain/komunitas lain cendrung berbeda, karena didasarkan pada karakter, sifat dan pengalaman hidup yang berbeda pula.

Sebagai prinsip berpikir dan bertindak keberadaan pandangan hidup mempunyai nilai penting bagi seseorang/komunitas untuk meraih kebajikan dalam hidup. Berdasarkan asalnya, pandangan hidup dapat diklasifikasikan menjadi tiga macam, yaitu; 1) pandangan hidup yang berasal dari kitab suci, dan dianggap mutlak kebenarannya bagi yang mengimani. 2) pandangan hidup yang berupa ideologi, yang disesuaikan dengan kebudayaan dan norma yang berlaku dalam satu negara. 3) pandangan hidup yang berasal dari renungan subjektif. Bagi komunitas Blatêr memiliki pandangan hidup dan prinsip merupakan unsur penting untuk memperjelas keinginan, cita-cita, dan juga arah hidup dalam dunia keblatèran. Wataknya yang agamis, loyalitasnya pada negara, dan tipikal gaya hidupnya yang eksentrik menjadikan pandangan hidup Blatēr dinuansai oleh semuanya ${ }^{2}$.

Kecendrungan Blatēr yang teguh memegang prinsip, senantiasa diterapkan pada dirinya sendiri dan orang lain. Saat dirinya merasa bersalah karena sala téngka (berbuat salah) pada orang lain, siapapun orangnya ia akan berusaha meminta maaf. Tapi jika orang lain yang sala téngka, dan orang lain tersebut mengakui kesalahan dan meminta maaf, maka pasti dimaafkan terkecuali kesalahan yang berkenaan dengan aléngka syahedet atau aléngka pagher ${ }^{3}$. Saking teguhnya Blatēr memegang prinsip, ia tidak mudah berubah haluan hanya karena iming-iming materi. Apa yang menjadi kesepakatan dengan orang lain selalu dirujukkan kepada prinsipprinsip sebagaimana dalam pandangan hidupnya. Hasil kesepakatan tersebut akan terus dipegang apapun resikonya, bahkan nyawa taruhannya.

Pembelaan pada prinsip dan kesepakatan yang dihasilkan dalam interaksi sosial, menjadi penentu integritas Blatēr sebagai orang yang konsisten/istiqamah (baca; jeg jeg) walaupun dalam keadaan yang sulit melakukannya. Sekurang-kurangnya, ada lima prinsip yang dipegang oleh komunitas Blatēr, sebagai berikut; 1) Ketauhidan, 2) Hormat kepada Embho' (Ibu), 3) Hormat kepada Ghuru (Guru), 4) Ajhegeh Téngka (menjaga etika), 5)

\footnotetext{
${ }^{2}$ Muniri, Titik Temu Pandangan Hidup Kalangan Blatĕr dan Pemikiran Murjiah. Pendidikan dan Keislaman. Jurnal Al-Fikrah. Vol. 1 No. (2021).

3 Bagi kalangan Blatēr, pengertian dari alengka syahedet atau alengka pagher yaitu mengganggu kekasih orang atau mengambil istri orang.
} 
Ajhegeh Harga Dirit ${ }^{4}$ Lima prinsip ini, sangat mungkin bertambah seiring dengan adanya hasil observasi dan penelitian lanjutan. Paling tidak beberapa prinsip komunitas Blatēr yang disebutkan di atas, menjadi pengantar bagi para peneliti dalam menemukan prinsip-prinsip yang belum tercover.

\section{Tahapan Pembentukan Prinsip-prinsip Komunitas Blatēr}

Interaksi sosial merupakan hubungan timbal balik yang dinamis antara seseorang dengan orang lain, antara seseorang dengan sekelompok orang, dan antara sekelompok orang dengan sekelompok manusia lainnya ${ }^{5}$. Interaksi yang terjadi menyebabkan saling mempengaruhi satu sama lain dengan tujuan terjadi penyesuaian diri. Ada dua syarat terjadinya interaksi sosial, ada kontak sosial sebagai cara berinteraksi sosial, dan komunikasi sebagai proses penyampaian dan penerimaan pesan (ide/gagasan) dari satu pihak kepada pihaklain ${ }^{6}$. Semakin baik komunikasi yang dilakukan akan mempermudah penyampaian dan penerimaan ide/gagasan, yang berefek pada cepatnya pengaruh dan penyesuaian diri. Maka dari itulah, komunikasi menjadi penentu kualitas interaksi sosial, baik yang verbal maupun nonverbal7. Adapun pengaruh dan penyesuaian diri yang diterima oleh seseorang dalam interaksi sosialnya, dengan beberapa faktor, yaitu; Pertama, Imitasi. Merupakan dorongan untuk meniru prilaku figur otoritas di lingkungan keluarga, misalnya orang tua, saudara, dan kerabatnya yang sering berinteraksi dalam sehari-hari. Imitasi ini, menjadi pembenaran bahwa manusia sebagai anak lingkungan, dan lingkungan

${ }^{4}$ Prinsip Blatér ini merupakan hipotesa Penulis, hasil rangkuman dari beberbagai literatur dan sudah dikonfirmasi secara terpisah kepada beberapa Blatér dengan inisial SA, AH, dan NS. Ketiganya merepresentasikan sebagai orang yang tahu tentang dunia Blatér, dan memberikan afirmasi terhadap hasil hipotesa ini. Sebenarnya Penulis mengajukan prinsip yang ke enam; "Jhe' loppah asadeka", tapi menurut mereka prinsip ini tidak termasuk, tapi bagian dari ajhegeh téngka.

${ }^{5}$ Soerjono Soekanto, Sosiologi Suatu Pengantar, (Jakarta: Rajawali Pers, 2012), 55

${ }^{6}$ Kontak sosial ada dua bentuk; primer dan sekunder. Kontak sosial primer adalah hubungan yang terjadi antara seseorang dengan orang lain yang dilakukan secara langsung dalam satu tempat dan waktu yang sama. Sedangkan kontak sosial sekunder merupakan sebaliknya, bisa melalui telpon, surat, radio, televisi dan media komunikasi tidak langsung lainnya. Ibid, 59-60

${ }^{7}$ Komunikasi verbal adalah komunikasi yang menggunakan simbol-simbol atau kata-kata yang digunakan secara oral atau lisan maupun tulisan. Sedangkan komunikasi nonverbal adalah pertukaran pesan dengan tidak menggunakan kata-kata melainkan dengan nada suara, gerakan tubuh dan lain-lain. Lihat dalam M. Budyatna dan Leila MG, Teori Komunikasi Antar Pribadi, (Jakarta: Kencana, 2011), 110 
paling kecil adalah keluarga ${ }^{8}$. Dalam kontek orang menjadi Blatēr sangat mungkin dikarenakan seringkali melihat prilaku dan mendengar pembicaraan sekitar konsep keblatēran dari orang-orang di lingkaran keluarga dan kerabatnya.

Kedua, Sugesti. Pemberian pengaruh kepada dirinya dan orang lain tentang suatu pendapat yang diterima secara sadar maupun tidak sadar tanpa reserve atau tanpa kritik, lebih cendrung karena alasan psikis9. Misalnya, karena kepercayaan diri yang amat tinggi sehingga merasa tidak butuh pendapat orang lain, dan hanya percaya pendapatnya yang paling benar. Sedangkan yang datang dari diri lain, karena terlalu memfigurkan seseorang hingga pada derajat memiliki otoritas kebenaran. Sebab lainnya, bisa dikarenakan terlalu fanatik pada komunitas yang menaunginya dan menjadikan keputusan komunitas dianggap benar, baik dan harus diikuti. Ketiga, Identifikasi. Merupakan tindakan lanjutan dari proses sugesti dan imitasi yang berpengaruh kuat pada diri seseorang ${ }^{10}$. Walaupun sama-sama tindakan 'meniru', tapi berbeda dalam prosesnya. Kalau imitasi merupakan tindakan 'meniru' tingkah laku, penampilan, atau sikap seseorang secara berlebihan melalui lingkaran kecil keluarga, maka identifikasi terjadi di luar lingkungan keluarga atas dorongan kecendrungan seseorang untuk 'menjadi sama' dengan sang Idola karena kedudukan sosialnya. Tidak penting sang idola tersebut dikenal langsung maupun tidak langsung. Biasanya, sang Idola merupakan figur otoritas dalam dunia yang digelutinya. Misalnya, seorang yang baru terjun dalam dunia Blatēr akan cendrung mengidolakan figure Blatēr yang secara kualitas jauh di atasnya. Ia akan berusaha mengedintifikasi dirinya dengan Blatēr yang dimaksud.

Keempat, Simpati ${ }^{11}$. Rasa simpati merupakan proses kejiwaan individual yang mengalami ketertarikan kepada seseorang/kelompok orang karena sikap, penampilan, wibawa, atau perbuatannya. Perasaan tertarik ini, sangat berpengaruh penting pada seseorang dalam proses penyesuaian diri. Biasanya, hanya keinginan memahami pihak lain dan untuk bekerja sama dikarenakan pihak lain tersebut mempunyai kelebihan atau kemampuan tertentu yang patut dicontoh. Adapun bentuknya dibagi dua; simpatik searah dan simpatik timbal balik ${ }^{12}$. Misalnya, rasa simpati

\footnotetext{
8 Abu Ahmadi, Psikologi Sosial, (Semarang: Rineka Cipta, 2007), 52

${ }^{9} \mathrm{Ibid}, 53$

${ }^{10} \mathrm{Ibid}, 57$

${ }^{11}$ Lihat https://id.wikipedia.org/wiki/Simpati, mengutip dari Tear, J; Michalska, KJ (2010). "Neurodevelopmental changes in the circuits underlying empathy and sympathy from childhood to adulthood". Developmental Science. 13 (6): 886-899.

${ }^{12}$ Abu Ahmadi, Psikologi Sosial,... 58
} 
yang dialami oleh bajhingan kepada Blatēr tanpa sepengetahuannya, karena kharisma yang miliki Blatēr ditengah masyarakat. Simpati yang seperti ini, disebut simpatik searah. Sedangkan simpatik timbal balik, adalah rasa simpati yang kedua belah pihak sama-sama tahu. Biasanya, akan menghasilkan hubungan kerjasama yang baik dan saling menguntungkan. Lima faktor interaksi sosial ini, akan dialami langsung oleh Blatēr dalam momentum remoh ${ }^{13}$. Komunitas Blatèr menjadikan remoh sebagai media melakukan kontak sosial dan komunikasi, sebuah ajang bertemu dengan Blatēr lainnya. Proses imitasi, sugesti, identifikasi, dan simpati antara Blatêr satu dengan lainnya diharapkan maksimal. Tapi, hasilnya tergantung reaksi masing-masing Blatēr. Kemampuan berintegrasi yang dimiliki menjadi penentu utama menjadikan ajang remoh sebagai momentum bagi Blatēr untuk ngokor abhe' (mengukur diri), untuk mengetahui seberapa tinggi pengakuan orang lain (sesama Blatēr) kepada dirinya. Selain itu, sebagai ajang Blatèr lain menilai dirinya. Seberapa baik dalam menjalin interaksinya dengan sesama Blatēr, sikap terbukanya kepada sesama Blatēr, sikap partisipatifnya dalam bekerja sama, sikap pedulinya terhadap masalah semasa Blatēr, dan kemampuannya dalam menjaga hubungan persahabatan sesama Blatēr.

Kemampuan integrasi Blatèr dalam momentum remoh merupakan upaya penyesuaian diri bertujuan menjalin hubungan baik dengan sejawatnya, dalam rangka mempertahankan eksistensinya atau survivalnya dalam dunia keblatēran. Selain itu, sebagai konformitas yang berarti penyesuaian diri dengan standart nilai atau prinsip-prinsip keblatêran. Usaha konformitas ini, menyiratkan keharusan dan komitmen menghindarkan diri dari penyimpangan prilaku yang bersebrangan dengan prinsip-prinsip keblatēran. Kesuksesan Blatēr dalam melakukan penyesuaian diri berpengaruh pada eksistensinya di lingkaran Blatēr untuk mendulang ekspektasi sosial setaraf dengan kiprah keblatēran. Tentu dalam perjalanan, pasti menghadapi ketegangan yang datang dari internal dan eksternal. Dari eksternal bisa berupa konflik dengan orang lain. Sedangkan dari internal, bisa berupa frustasi yang dapat menyebabkan mentalnya goyah. Agar Blatēr terbebas dari ketegangan yang dialami, maka ke-ajeg-

\footnotetext{
${ }^{13}$ Remoh dibedakan antara remoh warga biasa dan remoh Blatēr. Jika yang melakukan orang biasa, hanya sekedar perkumpulan orang yang saling memberikan sumbangan dalam hajatan keluarga, seperti pesta pesta perkawinan dan sejenisnya. Sedangkan remoh Blatēr, khusus perkumpulan para jago, atau orang yang hendak mendayung identitas keblatêran walaupun belum pernah terlibat dalam peristiwa carok. Lihat dalam Abdur Rozaki, Islam, Oligarki Politik, dan Perlawanan Sosial, (Yogyakarta: SUKA Press, 2016), 91
} 
annya menjadi taruhan dalam mengatasi kemungkinan-kemungkinan buruk yang akan terjadi. Dalam menguji ke-ajeg-an, biasanya Blatēr tidak langsung abak grabak (langsung pukul) saat mau menyelesaikan masalah dengan orang lain. Tapi cendrung mekker lanjheng (dipikir secara matang) siapa yang menjadi lawannya. Kalau sekiranya satu lawan satu dihitung bisa menang, pertimbangan selanjutnya adalah kekuatan di baliknya, bisa orang tuanya, saudaranya, dan lebelenah (kerabatnya) dari orang yang menjadi target. Setelah dihitung seimbang, yang bersangkutan melanjutkan pamit (minta idzin) pada tetua yang dihormati dan mempunyai pengaruh di lingkaran keluarga atau tetua kampung/desa . Biasanya, tetua akan memberikan satu saran, yaitu mekker lanjheng. Saran dari tetua cukup memberikan pengaruh signifikan, tapi seringkali kalau berhubungan dengan harga diri yang sangat prinsipil seperti kasus aléngka syahedet, saran ini cendrung tidak diikuti. Karena tujuan yang bersangkutan bukan mendapatkan ijin, melainkan hanya bersifat pemberitahuan.

Lima prinsip Blatêr, ketauhidan, hormat kepada Embho' (Ibu), hormat kepada ghuru (Guru), ajhegeh téngka (menjaga etika), dan ajhegeh harga diri menjadi bagian modal interaksi sosial komunitas Blatēr dalam momentum remoh. Bagi Blatēr pemula, informasi sekitar dunia keblatēran yang didapatkan dari figur di lingkungan keluarganya, akan dicocokkan secara langsung dengan prilaku Blatêr dalam remoh tersebut. Pada tahap selanjutnya, pengalaman interaksi langsung dengan komunitas Blatēr akan disugestikan kepada dirinya tanpa reserve. Lambat laun, seiring niat menjadi Blatēr akan melakukan identifikasi dirinya dengan karakteristik seorang Blatēr, dengan mengakomodir prinsip-prinsip hidup Blatēr hingga berpengaruh pada prilaku dan gaya bicaranya. Selama interaksi dalam remoh ke remoh lainnya. Blatēr pemula akan mulai memilah dan memilih figur Blatêr rajah yang mana hendak dijadikan panutan dan dijadikan parembaghan (tempat suaka dan meminta saran).

\section{Prinsip-prinsip Komunitas Blatér dalam Telaah Ajaran Agama Islam}

Beberapa prinsip Blatér yang disebutkan di atas, merupakan hipotesa Penulis yang sudah dikonfirmasikan kepada beberapa Blatér. Mereka, mengafirmasi lima prinsip saja dari enam prinsip yang diajukan. Sejumlah prinsip ini, tentu lahir dari pergulatan panjang dari cakrawala pada masa lalu dalam gerak melingkar terus-menerus yang dimiliki hingga terakumulasi menjadi sebuah prinsip. Dalam hal ini, perjumpaan kecendrungan hidup Blatér dengan budaya lokal dan ajaran Islam melebur dalam kesadaran historis yang membentuk rumusan prinsip-prinsip 
hidupnya. Dengan prinsip-prinsip hidup itulah, Blatér bermaksud menjelaskan dunianya kepada khalayak ${ }^{14}$. Untuk memahaminya, tentu dengan cara meletakkan prinsip-prinsip tersebut dalam lingkup historis, sehingga menghasilkan makna yang bersifat historis.

Kondisi ekonomi yang kurang beruntung, karena kondisi alam yang tandus dan budaya lokal yang keras, namun tetap butuh pembenaran agama atas sikapnya, mengarahkan Blatér menyeleksi ajaran-ajaran agama yang sesuai dan bisa diambil untuk mendukung prinsip-prinsipnya. Gambaran ini, sesuai dengan pendapat Moeslim Abdurrahman bahwa kultur setempat di mana seseorang dilahirkan sangat mempengaruhi pandangan hidup seseorang, hingga pada proses inkulturasi dan akulturasi keberagamaannya ${ }^{15}$. Maka secara epistemologis, prinsip-prinsip Blatér bukan sebagai tradisi berpikir mandiri melainkan hasil reaksi dan koreksi dari budaya lokal dan pada ajaran agamanya, yang sebenarnya masih berupa narasi yang bermakna subjektif, tetapi dipaksa menjadi narasi objektif dan dijadikan rujukan dalam interaksi sosial Blatér. Berikut penjelasan prinsip-prinsip Blatér menurut perspektif ajaran agama Islam;

\section{Ketauhidan}

Islam sebagai agama mayoritas di Madura sangat berpengaruh pada pemberian definisi orang Madura. Hal ini, bisa dilihat dari kecendrungan nilai sosial yang diserap dan dipakai oleh diri mereka yang menunjukkan jiwa Islami. Hanya saja, muncul tanda tanya tentang pilihan corak keislamannya, apakah segaris dengan ajaran Nahdlatul Ulama (NU), Muhammadiyah, Wahabi, Syi' ah atau aliran keislaman yang lain? Terlepas dari corak keislaman yang disebutkan, yang pasti orang Madura digambarkan berjiwa Islami, yang diilustrasikan dalam ungkapan abantal syahadat, asapo iman, apajung Alloh, bahwa dalam kehidupan mereka memakai syahadat sebagai alas kepala (cara berpikir), berselimut iman (arahan iman), dan berlindung kepada Allah, niscaya akan selamat. Khusus komunitas Blatér, kecendrungan corak pemikiran ketauhidannya ada

${ }^{14}$ Istilah cakrawali (horizon) berasal dari fenomenologi Husserl. Gadamer meminjam untuk menjelaskan jangkauan penglihatan yang mencakup segala hal yang dapat dilihat dari sudut pandang tertentu, yang menentukan kualitas pemahaman seseorang. Sedangkan cakrawala seseorang terbatas, dan tidak mungkin melampaui cakrawala yang dimilikinya. Dengan cakrawala yang terbatas itulah, seseorang berusaha meleburkannya hingga menjadi sebuah pemahaman. Lihat Budi Hardiman, Seni Memahami: Hermeneutik dan Schleiermacher sampai Derrida, (Yogyakarta: Kanisius, 2015), 163

${ }^{15}$ Moeslim Abdurrahman Wahid, Islam sebagai Kritik Sosial, (Jakarta: Erlanga, 2003), 149 
kesamaan dengan pemikiran Murjiah, yang memasrahkan urusan keimanan hanya Allah yang tahu. Walaupun komunitas Blatér mengakui tidak begitu serius dalam beribadah mahdhoh, bahkan sering meninggalkannya, sering melakukan maksiat dan dosa besar. Mereka tetap bersikukuh sebagai orang yang beragama Islam, dan sangat fanatik. Dalam beberapa kesempatan ungkapan; "sé penting engko' islam macah Syahadat, orosen akherat pecca'eh Alloh" (Yang penting Saya Islam dan membaca Syahadat, terkait nanti di akhirat itu menjadi urusan Allah) sering keluar dari mulut Blatér saat sesi wawancara tidak terstruktur.

Sejumlah pandangan hidup Blatér yang ditengarahi ada kesamaan dengan pemikiran Murjiah, dalam pembahasan tentang iman Islam. Keduanya, sama-sama berpendapat bahwa Iman Islam akan menyelamatkan seseorang nanti di akhirat, dan sama sekali tidak tergantung dengan perbuatannya selama hidup di dunia. Walaupun semasa hidup sering melakukan perbuatan maksiat dan melakukan dosa besar, asalkan tetap beriman-Islam di hatinya, kelak di akhirat tetap berhak mendapatkan rahmat dan masuk ke dalam Surga Allah. Bagi mereka, segala yang diperbuat selama di dunia hanya Allah yang berhak menilainya, dan keputusan resminya nanti di akhirat. Penilaian Allah pasti seadil-adilnya penilaian, karena sebagai dzat yang Maha Adil. Murjiah berpendapat serupa, selama seseorang percaya kepada Allah dan Rasulnya, meskipun hitungan dosanya melebihi lautan tetap mendapatkan rahmat dan masuk Surga, karena sama sekali tidak mempengaruhi kualitas iman seseorang. Dan kalaupun perbuatan yang dilakukan adalah dosa besar, Allah tetap mengampuni asal bukan dosa syirik ${ }^{16}$. Kesamanaan pandangan hidup Blatér dan pemikiran Murjiah, mendapatkan pembenaran dalam sebuah hadits yang menyatakan, bahwa barang siapa membaca Lailaha illallah, pasti masuk Surga. Namun, ada yang mengsyaratkan bisa masuk Surga selama bukan dosa syirik. Penjelasan syarat diampuni dosa seseorang terdapat dalam ayat 48 surat Annisa; Sesungguhnya Allah tidak akan mengampuni dosa syirik, dan Dia mengampuni segala dosa selain (syirik) itu, bagi siapa yang dikehendakinya.

\section{Hormat kepada Embho' (Ibu)}

Dalam tradisi jawa ada ungkapan 'Gusti kang katon' (Tuhan yang terlihat). Analogi Ibu sedemikian rupa, karena dengan segala welas-asih dan kodrat

\footnotetext{
${ }^{16}$ Penjelasan kesamaan pandangan hidup blatér dan pemikiran Murjiah bisa di baca dalam; Muniri, Titik Temu Pandangan Hidup Kalangan Blatĕr dan Pemikiran Murjiah. Pendidikan dan Keislaman. Jurnal Al-Fikrah. Vol. 1 No. (2021).
} 
keibuannya, ia pantas menyandang sebutan Ibu. Bahkan ada hadits yang menyatakan bahwa "Surga berada di bawah telapak kaki Ibu"17. Dua ungkapan ini, tentu hanya sebatas kiasan betapa seolah Tuhan menampakkan Rahman-Rahimnya melalui sosok Ibu, bukan berarti Tuhan menampakkan diri menjadi Ibu. Makanya, restu dan do'a Ibu sangat diharapkan oleh seorang Blatér, karena dianggap menentukan sepak terjangnya. Cukup banyak kisah-kisah tentang keramat sosok Ibu, seperti cerita Uwais Al-Qarny. Ia hidup di zaman Nabi Muhammad SAW, dan mendapat derajat kewalian karena memulyakan Ibunya. Uwais menggendong Ibunya dari tempat asalnya ke Mekah dan Madinah untuk melaksanakan Haji, saat di depan ka'bah Ibunya menawarkan mau dido'akan apa kepada Allah, ia menjawab; "Ibu saja yang berdo'a, cukuplah Saya mendapat ridha Ibu saja. Cerita lainnya, sosok Syarif Tambak Yoso. Diceritakan, ia seorang pejuang yang badannya kebal, semua bentuk senjata tidak mempan. Ternyata kekuatannya bukan karena mempunyai jimat, melainkan karena memiliki seorang Ibu yang sangat ia hormati. Bahkan saking keramatnya, ia cukup memanggil Ibu saat dirundung kesusahan dan saat terluka dipeperangan dan hampir sekarat. Cerita tentang Ibu yang mewakili murka Ibu, seperti dalam cerita Malin Kundang. Do'a dan restu Ibunya menghantarkannya menjadi saudagar kaya dan dihormati karena menikah dengan anak saudagar kaya. Tapi kemudian, ia malu mengakui Ibunya di depan Istri dan anak buahnya karena Ibunya terlihat seperti gembel.

Menguatkan posisi Ibu dalam diri anak-anaknya, Nabi Muhammad menjawab; Ibumu, Ibumu, Ibumu (menyebut tiga kali), lalu Ayahmu, saat ditanya tentang siapa yang harus dihormati di dunia ini ${ }^{18}$. Dalam hadits yang lain diterangkan, bahwa ridha dan murka kedua orang tua satu kesatuan dengan ridha dan murka Allah ${ }^{19}$. Ditegaskan juga dalam AlQur'an, yang artinya; "Dan Tuhanmu telah memerintahkan supaya kamu jangan menyembah selain Dia dan hendaklah kamu berbuat baik pada Ibu-Bapakmu dengan sebaik-baiknya. Jika salah seorang di antara keduanya atau kedua-duanya sampai berumur lanjut dalam pemeliharaanmu, maka sekali-kali janganlah kamu mengatakan kepada keduanya perkataan "ah" dan janganlah kamu membentak mereka dan ucapkanlah kepada mereka perkataan yang mulia". ${ }^{20}$ Dalam ayat ini, setelah memerintahkan menyembah-Nya, selanjutnya Allah mewajibkan

\footnotetext{
${ }^{17}$ HR. Anas bin Malik

${ }^{18}$ HR. Bukhari

${ }^{19}$ HR. Bukhari

${ }^{20}$ QS. Al-Isra: 23
} 
berbuat baik kepada kedua orang tua. Latar belakang inilah, bagi kalangan Blatér kedua orang tua, terutama sosok Ibu sangat penting dan dianggap sebagai 'jimat' hidup.

\section{Hormat kepada Ghuru (Guru)}

Mungkin tidak banyak yang tahu tentang asal-usul pribahasa "Bhuppa', Bhabbu', Ghuru, Rato", lahir dari perdebatan dua tokoh di Madura Barat (Bangkalan) dulu kala; Buju' Langgurdih dan Buju' Sembilangan. Saat itu, kalangan kerajaan Bangkalan dan Pemerintah Hindia Belanda sedang berhubungan baik, dan terkesan menjadi kepanjangan tangan dari Pemerintah Hindia Belanda. Munculnya, pernyataan "Laa ma'buda bi haqqin illallaahi" yang disinyalir mengandung makna bahwasanya "haram hukumnya menyembah ratu", membuat goyah kekuasaan Pemerintah Hindia Belanda di Bangkalan saat itu. Menurut Buju' Langgurdih, manusia hanya wajib menyembah Allah semata, dan tidak ada keterwakilan penyembahan kepada makhluknya, termasuk kepada ratu. Dalil yang dipakai adalah "Laa ma'buda bi haqqin illallahi" untuk menegaskan keharaman menyembah ratu. Keluarnya fatwa ini, membuat pemerintahan Hindia Belanda merasa takut akan menyebabkan ketundukan masyarakat menjadi luntur dan tergerak melakukan pembangkangan sipil. Polemik pernyataan Buju' Langgurdih berlangsung dalam beberapa tahun, dan ditanggapi oleh Buju' Sembilangan dengan mengatakan bahwa konsep "Laa ma'buda bi haqqin illallaahi" tidak dapat dikaitkan dengan larangan menyembah ratu. Menurutnya, pemimpin merupakan wakil dalam tatanan sosial yang ditujukan guna menciptakan keteraturan dan ketertiban hukum-hukum yang merupakan sunnatullah dalam masyarakat ${ }^{21}$.

${ }^{21}$ Dalam khazanah pemikiran keislaman, ada tiga pendapat tentang hubungan negara dan agama. Yang pertama, pendapat al-Maududi (w. 1979), yang meniscayakan adanya unifikasi antara Islam dan negara. Sebab wilayah negara juga meliputi politik. Negara menyelenggarakan segala sesuatunya atas dasar kedaulatan Tuhan, dikarenakan kedaulatan yang dimiliki berasal dan berada di "Tangan Tuhan". Kedua, pendapat dari al-Mawardi (w.1058) dan al-Ghazali (w.1111), yang menggambarkan hubungan symbiosis antara negara dan agama. Agama memerlukan negara akan berkembang, sebaliknya negara membutuhkan agama sebagai pembimbing etika dan moral. Ketiga, mengajukan paradigma sekuler, dengan menolak unifikasi dan simbiosa negara dan agama. Bahkan perlu ada dikotomi agar tidak terjadi determinisme agama oleh negara. Melihat dari penjelasan ini, pendapat Buju' Sembilangan yang menyatakan pemerintahan adalah wakil Tuhan untuk memberikan tatanan masyarakat yang baik, ada kesamaan dengan pendapat al-Maududi. Lihat Muniri, Fatwa MUI dan Implikasinya Terhadap Hubungan Agama - Negara; Studi Power/Knowledge Michel Foucault Atas Fatwa 
Karenanya, tidak dibenarkan melakukan pembangkangan terhadap penguasa yang mendapat mandat tersebut ${ }^{22}$.

Pendapat Buju Sembilangan ini, ditengarai sebagai penguat kekhususan kultural pada ketaatan, ketundukan, dan kepasrahan orang Madura kepada empat figur utama dalam kehidupan, antara lain; Bhuppa', Bhabu', Ghuru, Rato (Ayah, Ibu, Guru, dan Pemimpin pemerintahan). Kepada figur-figur utama inilah kepatuhan hierarkis orang-orang Madura menampakkan wujudnya dalam kehidupan sosial budaya mereka ${ }^{23}$. Tentu tidak terkecuali komunitas Blatér juga menjadikan kepatuhan hierarkis ini sebagai prinsip hidupnya, namun mempunyai titik tekan berbeda dengan masyarakat umum. Blatér memberikan penekanan kepada sosok Ibu dan guru yang harus dihormati dalam rangkaian kata Bhuppa', Bhabu', Ghuru, Rato. Sementara penghormatan selanjutnya kepada sosok guru, tapi istilah guru yang dimaksud bukan merujuk kepada guru secara umum, melainkan kepada sosok Kiyai (figur agamawan)24. Umumnya, Blatér menaruh rasa hormat kepada Kiyai karena alasan ilmu agama yang dimiliki dan ibadahnya kepada Allah SWT. Dengan dua keunggulan yang dimiliki, sosok Kiyai diasumsikan sebagai orang yang dekat dengan Allah. Dan tidak ada orang yang dekat dengan Allah, kecuali orang yang pasti dikabulkan do'a-do'anya. Kualitas spiritual inilah, yang menjadikan Kiyai sebagai rujukan ummat dan wasilah (perantara) ${ }^{25}$. Secara psikologis, sosok

MUI Tentang Pluralisme, Liberalisme, dan Sekulerisme Agama. Skripsi. Fak. Syariah, Jurusan Siyasah Jinayah, IAIN Sunan Ampel Surabaya, 2008.2-3

${ }^{22}$ Muniri Chodri, KH. Asy'ari Umar; Ulama Mandiri Pengokoh Tradisi, (Surabaya: Imtiyas, 2012), 16-18

${ }^{23}$ Latief Wiyata, Madura yang Patuh?; Kajian Antropologi Mengenai Budaya Madura, (Jakarta: CERIC-FISIP UI, 2003), 1

${ }^{24}$ Ridwan Ahmad Sukri, Konsep Bapa', Babu, Guru, Rato pada Masyarakat Madura Sebagai Wujud Pengamalan Sila ke-2 Pancasila, Jurnal Filsafat, edisi ke-30. Oktober 1999. Bisa didownload di https://media.neliti.com/media/publications/228402-konsepbapababuguru-raton-pada-masyaraka-7a19c5d2.pdf

25 Prilaku kalangan Blatér dalam menjadikan Kiyai sebagai wasilah mendapatkan keselamatan dan keberkahan hidup, ada argumentasi pembenaran dari Muhammad ibn 'Alawi yang mengutip Surat al-Maidah:[5]; 35 yang berbunyi: "Hai orang-orang yang beriman! Bertakwalah kepada Allah dan bersungguh-sunggulah mencari jalan yang mendekatkan diri kepada-Nya, dan berjihadlah pada jalan-Nya, supaya kamu mendapat keberuntungan". Dalam memaknai ayat ini, Muhammad ibn "Alawi mengatakan bahwa kata wasilah (perantara) yang ada dalam ayat tersebut menunjukkan umum. Artinya, kata ini berlaku bagi manusia yang memiliki keutamaan atau perbuatan yang shaleh. Dengan maksud berperantara dengan para nabi dan orang-orang shalih baik masih hidup ataupun telah meninggal atau berperantara dengan perbuatan baik sesuai dengan yang diperintahkan. 
Blatér yang hidup dalam dunia hitam, dan dekat dengan bahaya memerlukan do'a-do'a keselamatan dan berkah kehidupan, tidak hanya dari Ibunya melainkan juga dari Kiyai yang dianggap mandih duwenah (do'anya gampang terkabul).

\section{Ajhegeh Téngka (menjaga etika)}

Secara umum orang Madura sangat menghormati nilai-nilai kesopanan yang termanifestasikan keluar (orang lain/tidak ada ikatan darah) dan kedalam (keluarga/kerabat sepertalian darah). Komunitas Blatér dalam hal ini, terlihat sangat menonjol dalam menjaga etika kesopanan keluar. Tampak sekali prilakunya, dalam memelihara jalinan persaudaraan sejati, yang tergambar dalam ungkapan pribahasa; "oréng dhaddi tarétan, tarétan dhaddi oréng (orang lain bisa dianggap sebagai saudara sendiri, sedangkan saudara sendiri bisa dianggap sebagai orang lain). Sebagai orang Madura, komunitas Blatér menganggap persaudaraan tidak selalu identik dengan hubungan darah kekerabatan, tetapi juga pada pertemanan. Sebaliknya, orang yang masih mempunyai pertalian darah, berkemungkinan berubah menjadi permusuhan karena persoaalan yang tidak bisa diselesaikan secara kekeluargaan ${ }^{26}$. Demikian juga dalam menjunjung etika kesopanan dalam rangka ajhegeh téngka, tergambarkan dalam pribahasa; mabenah 'kan talpaktana, ghi' maba'an pole, yang artinya serendah-rendahnya orang Madura dalam memberikan penghormatan, masih lebih rendah lagi dalam menghormati orang lain". Pribahasa ini, mengajarkan cara memberikan penghormatan kepada orang lain, jika orang lain memberikan penghormatan kepada kita, maka kita harus lebih menghormati pada mereka. Salah satu upaya ajhegeh téngka lainnya, dengan tidak mengurusi urusan orang lain, lebih fokus menata posisi diri sendiri dalam kontek pergaulan sosial seluas-luasnya, sekaligus memberikan tuntutan pentingnya sikap jeg jeg (istiqamah), seperti dalam pribahasa; "lakona lakone, kennenga kennengngi" (Kerjakan dengan baik apa yang menjadi pekerjaanmu, dan tempati dengan baik pula apa yang telah ditetapkan sebagai tempatmu).

Sedangkan manifestasi kesopanan kedalam, seperti ungkapan pribahasa; "rampak naong, beringin korong", yang artinya: suasana teduh

Lihat Muhammad Ibn Alawi Al-Maliki, Mafahim Yajibu 'an Tusahha, (Dubai: Dairah alAwqaf wa al-Shu'un al-Islamiyyah, 1995), 117

${ }^{26}$ A. Latief Wiyata, Carok; Konflik Kekerasaan dan Harga Diri Orang Madura, (Yogyakarta: LKIS, 2002), 61 
penuh kedamaian layaknya berada di bawah pohon beringin yang rindang. Mengedepankan nilai-nilai kehidupan yang penuh harmoni dalam relasi kekeluargaan dan kekerabatan. Selain itu, jika sudah mempunyai banyak harta (kaya raya), orang Madura mempunyai kewajiban moral menjadi penyangga penderitaan orang miskin, dengan bersikap luman (lambhe' ta'cerre') kepada semua orang yang membutuhkan uluran tangannya karena menjadi salah satu upaya ajhegeh téngka, seperti yang tergambarkan dalam pribahasa; mon sogi, pasoghe ${ }^{27}$. Etika orang Madura ini, masih dipelihara dan dilakukan oleh kalangan Blatér dan menjadi identitas kedirian komunitas Blatér. Dengan identitas kedirian ini, sebenarnya komunitas Blatér telah melaksanakan perintah agama, yaitu mengamalkan ayat 63 surat Al-Furqan; "Dan hamba-hamba Tuhan yang Maha Penyayang itu (ialah) orang-orang yang berjalan di atas bumi dengan rendah hati dan apabila orang-orang jahil menyapa mereka, mereka mengucapkan kata-kata (yang mengandung) keselamatan mereka". Dengan siapapun seorang Blatér berinteraksi, jangankan dengan orang baik, dengan orang buruk prilakunya sekalipun, tetap menunjukkan sisi keakraban dan kesantunan. Karena dengan komunikasi yang akrab dan santun, permusuhan dapat dihindari bahkan cendrung berubah menjadi pertemanan. Namun tidak mengurangi kewaspadaan dalam mengamati orang-orang sekelilingnya, bahkan Blatér mempunyai kepiawaian dalam mengamati karakter seseorang, utamanya menilai kebaikan dan kejahatan orang lain. Prilaku yang sedemikian rupa, merupakan pengamalan ayat 34 surat Fushshilat; "Dan tidaklah sama kebaikan dan kejahatan. Tolaklah (kejahatan itu) dengan cara yang lebih baik, maka tiba-tiba orang yang antaramu dia ada permusuhan seolaholah telah menjadi teman yang sangat setia". Bahwa sopan santunlah yang lebih mampu meraih simpati dan menciptakan hubungan baik baik dibandingkan dengan apapun selainnya, termasuk iming-iming materi. Menguatkan ayat ini, hadits Nabi SAW menjelaskan; "kalian tidak dapat menjangkau semua orang dengan harta benda kalian, tapi mereka dapat terjangkau oleh kalian dengan wajah yang cerah dan akhlak yang luhur". ${ }^{28}$ Diceritakan pula dalam sebuah hadits, ada orang yang menghadap Nabi SAW. Sebelum orang tersebut datang, Nabi menceritakan perangai buruk orang tersebut kepada Siti Aisyah RA. Setelah orang tersebut pergi, Siti Aisyah bertanya;

27 Modul Pendidikan Kedamaian Berbasis Pesantren Tahun 2006 di Hotel Madinah Pamekasan. Ditulis di web Konsensus Bhiruh Dheun. Bisa dibaca di https://blog.bhiruhdheun.com/aneka-pribahasa-madura-etos-kerja-dan-hubungansosial/

${ }^{28} \mathrm{HR}$. Al-Bazzar 
"Wahai Nabi! Engkau tadi (dihadapanku) tetap berucap (buruk) menyangkut perangai orang itu, tetapi engkau tetap berlemah lembut terhadapnya". ${ }^{29}$ Dari penjelasan ini, bukan berarti Penulis menganggap akhlak Blatér sudah sepenuhnya sesuai tuntunan Al-Qur'an dan Hadits, tapi paling tidak komunitas Blatér diakui sebagai komunitas yang sangat menjaga etika perkawanan sosial. Bahkan ada ungkapan, bahwa akhlak Blatér rajah (yang kelas tinggi), akhlaknya mirip dengan akhlak Kiyai yang alim, dalam hal memberikan penghormatan kepada orang lain tanpa pandang bulu.

\section{Ajhegeh harga diri}

Orang Madura sangat menjaga kekerabatan dan perkawanan sosial. Untuk menjaga itu, yang dikedepankan dalam menyelesaikan konflik adalah musyawarah, dan seringkali berakhir dengan perdamaian dan saling memaafkan satu sama lain, selama belum ada korban nyawa. Lain lagi kalau konflik yang sudah ada korban nyawa, maka dari pihak pelaku sadar dan siap menerima balasan dari pihak korban. Selain kasus aléngka syahedet, dalam waktu yang tidak lama seringkali pihak korban akan melakukan pembalasan, atau dalam waktu beberapa tahun kemudian, saat pihak keluarga korban siap membalasnya. Kejadian carok hingga saat ini masih sering terjadi, walaupun sebenarnya sudah bukan lingkup definisi carok murni, karena sebenarnya carok merupakan sikap ksatria, pertarungan satu lawan satu, dengan waktu dan tempat yang sudah ditentukan. Kasus-kasus penghilangan nyawa di Madura akhir-akhir ini, dengan celurit atau senjata tajam lainnya mengesankan bukan carok melainkan kasus pembunuhan murni. Sebenarnya, carok sendiri merupakan upaya pembelaan atas harga diri, yang berhubungan dengan nilai dasar dan ukuran eksistensi diri yang harus dipertahankan agar tidak lagi direndahkan oleh orang lain. Yang bisa berbuat demikian, umumnya adalah orang Blatér. Jika orang biasa yang melakukan, maka orang tersebut dengan sendirinya akan mendapatkan predikat Blatér ${ }^{30}$.

Pembelaan terhadap harga diri orang Madura tergambarkan dalam ungkapan; "aotang pesse majar pesse, aotang nyaba majar nyaba" (jika berhutang uang harus bayar dengan uang, hutang nyawa harus dibayar dengan nyawa). Ungkapan ini, mengajarkan keberanian menanggung resiko dari perbuatan yang telah dilakukan, dan keharusan membalas perbuatan yang selayaknya harus dibalas sesuai kadarnya. Dalam tafsiran

\footnotetext{
${ }^{29}$ HR. Bukhari-Muslim

${ }^{30}$ Abdur Rozaki, Islam, Oligarki Politik, dan Perlawanan Sosial,...90-91
} 
lain, penerimaan atas hukum kesetimpalan, jika berbuat baik pada orang tentunya akan dibalas dengan kebaikan pula, demikian juga jika pernah berbuat jahat maka ganjarannya juga kejahatan atas mereka yang melakukan kejahatan. Ungkapan lainnya, adalah; "oreng lake' mate acarok, oreng bine' mate arembi' (laki-laki biasa mati karena carok, seperti perempuan mati karena melahirkan). Yang mengajarkan keharusan pada seorang lakilaki agar mempunyai sikap ksatria sepanjang hidupnya, sebagaimana keharusan pada perempuan agar mempunyai keberanian dalam mempertaruhkan nyawanya saat melahirkan anak-anaknya. Yang terakhir, ajaran agar selalu berhati-hati dalam berbicara dan bersikap agar tidak menyinggung orang lain sehingga menyebabkan sakit hati, karena kalau sampai orang lain tersinggung dan sakit hati suatu saat ia akan melakukan pembalasan yang lebih kejam dari apa yang kita perbuat. Ajaran ini tergambarkan dalam ungkapan; "lokanah daging bisa ejei', lakonah ate tada" tambanah kajebe ngero' dhere" (lukanya daging masih bisa diobati/dijahit, tetapi jika hati yang terluka tidak ada obatnya kecuali minum darah).

Kalau dianalisa dari motif terjadinya carok. Sepertinya, sama sekali tidak ada pembenaran atas perbuatan tersebut dalam ajaran agama. Walaupun, kenyataannya ajaran-ajaran Islam memberikan kontribusi yang cukup besar terhadap pembentukan nilai-nilai budaya masyarakat Madura $^{31}$. Tapi, khusus menjaga harga diri dengan membenarkan penghilangan nyawa tidak bisa dibenarkan, karena sepertinya murni ijtihad sikap budaya di luar ajaran agama. Berbeda dengan empat prinsip yang sebelumnya sudah dijelaskan, yang ada legitimasinya dalam ajaran agama, walaupun dalam pengamalannya disesuaikan dengan takaran kesanggupan dan khas Blatér. Dalam agama Islam sangat jelas larangan membunuh, terkecuali dalam tiga hal, sebagaimana diriwayatkan dalam sebuah hadits, yang artinya; "tidak halal membunuh seorang Muslim kecuali tiga hal; kufur sesudah beriman, berzina setelah berkeluarga, dan membunuh tanpa alasan yang benar karena semata berbuat dhalim dan permusuhan"32. Bahkan karena tegasnya larangan pembunuhan, jika ada dua pihak yang saling

${ }^{31}$ Mien Ahmad Rifai, Manusia Madura Pembawaan, Perilaku, Etos Kerja, Penampilan, dan Pandangan Hidupnya seperti Dicitrakan Peribahasanya,(Yogyakarta, Pilar Media, 2007), 347

32 Hadits ini diriwayatkan oleh Imam Muslim. Mengenai kebolehan menghilangkan nyawa orang lain, Wahbah Zuhaily menyatakan bahwa perbuatan menghilangkan nyawa karena alas an dendam atau untuk menebar kerusakan hanya dapat diputuskan oleh pengadilan yang berwenang. Bahkan selama dalam peperangan sekalipun, hanya dapat diadili oleh pemerintah yang sah. Dan tidak ada satupun seseorang yang memiliki hak untuk mengadili secara main hakim sendiri. Lihat Wahbah Zuhaily, Tafsir al-Munir fi alAqidah wa as-Syari'ah wa al-Manhaj, Jilid I (Damsik: Dar Al-Fikr, 2009), 480 
membunuh tanpa alasan yang dibenarkan oleh syara', maka pembunuh dan yang dibunuh sama-sama akan dimasukkan dalam neraka ${ }^{33}$. Demikian juga, bagi orang yang bersekongkol dalam pembunuhan, akan diberikan sangsi yang sangat berat. Meskipun hanya dengan sepotong kalimat yang berbau fitnah dan suruhan, maka orang diantara kedua matanya akan tertulis ungkapan putus asa/jauh dari rahmat Allah ${ }^{34}$. Ditegaskan pula dalam Al-Qur'an yang berbunyi; "dan janganlah kamu membunuh jiwa yang diharamkan Allah (membunuhnya), melainkan dengan suatu (alas an) yang benar. Dan barang siapa dibunuh secara zalim, maka sesungguhnya Kami telah memberi kekuasaan kepada ahli warisnya, tetapi janganlah ahli waris itu melampaui batas dalam membunuh. Sesungguhnya ia adalah orang yang mendapat pertolongan ${ }^{35}$. Berdasarkam dalil-dalil tentang larangan menghilangkan nyawa orang lain, ulama sepakat bahwa perbuatan menghilangkan nyawa orang lain termasuk kategori haram hukumnya, dan termasuk perbuatan dosa besar.

Dengan demikian, prinsip hidup ajhegeh harga diri sebagaimana yang dimaksud oleh komunitas Blatér tidak ada pembenarannya dalam ajaran agama, hanya sebatas refleksi spontan terhadap kebutuhan dasarnya. Menurut Abraham Maslow, semua manusia mempunyai hirarki kebutuhan dasar, dan manusia berkecendrungan mewujudkan secara bertahap ${ }^{36}$. Adapun kebutuhan yang paling dasar adalah fisiologis (Physiological Needs), yang meliputi; mendapatkan penghasilan, terpenuhinya sandang, pangan, papan, dan tubuh dan pikiran yang sehat (istirahat, seks, kesegaran jasmani, udara, air, hiburan, rekreasi dan sebagainya). Setelah kebutuhan fisiologis terpenuhi, kemudian beranjak mempertimbangkan kebutuhan akan rasa aman (Safety Needs). Manusia merasa perlu memperoleh perlindungan, perasaan bebas dari ketakutan, kecemasan dan kekacauan. Kemudian, dilanjutkan pada kebutuhan dicintai (Social Needs). Tapi bukan berarti dengan pemenuhan kebutuhan seks. Kebutuhan dicinta yang dimaksud berhubungan dengan kebutuhan sosial, seperti menjalin keakraban dengan orang lain, dan kebutuhan sebagai bagian dari kelompok tertentu. Adapun kebutuhan untuk dihargai (Esteem Needs), yang meliputi kebutuhan agar diakui, status, kedudukan, memiliki kekuasaan sosial, mendapatkan apresiasi orang lain atas keberhasilannya merupakan pengantar pada pemenuhan kebutuhan yang

\footnotetext{
${ }^{33}$ HR. Bukhari Muslim

${ }^{34}$ HR. Abu Daud

${ }^{35}$ QS. Al Isra: 33

36 Abraham H. Maslow, Motivation and personality, (USA: Harper and Row Publication, 1970), 35-47
} 
tertinggi yaitu kebutuhan aktualisasi diri (Self-actualization) sesuai koridor kebenaran, kejujuran, keindahan, dan kebaikan yang berlaku di tengah masyarakatnya.

Berdasar pada penjelasan hirarki kebutuhan dasar manusia menurut Maslow. Maka, prinsip hidup ajhegeh harga diri bagi Blatér merupakan pemenuhan kebutuhan dasar untuk mendapatkan penghargaan, seperti status sosial, kedudukan sosial dan kekuasaan sosial. Dan semua itu, menjadi penting untuk dipenuhi supaya mendapatkan pengakuan dan apresiasi sosial atas keberhasilannya. Semua capaian yang dimiliki, tidak boleh ada orang yang melecehkan karena berkaitan dengan malo (malu). Melecehkan harga diri sama dengan mengingkari kapasitas dirinya sehingga dia akan merasa tada' ajina (tidak dihargai). Hal-hal yang menjadi alasan merasa malo, jika berhubungan dengan harta, tahta, dan wanita. Dalam keadaan tidak kuasa menanggung malu, maka carok jalan terakhir dijadikan media pembelaan harga diri ketika diinjak-injak oleh orang lain, sebagaimana dalam ungkapan; étémbheng poté mata, lebih baghus poté tolang (daripada hidup menanggung perasaan malu, lebih baik mati berkalang tanah) ${ }^{37}$. Meskipun terdapat varian latar belakang berbeda motif terjadinya carok, akan tetapi mempunyai akar yang sama, yaitu perasaan malo karena harga diri yang dilecehkan, dan beranggapan hanya dengan melakukan carok harga dirinya dapat dipulihkan. Berdasarkan motif dan tujuan carok, tidak ada sama sekali pembenaran dalam ajaran agama Islam.

\section{Kesimpulan}

Pembentukan prinsip-prinsip hidup komunitas Blatēr, melalui beberapa tahapan antara lain; Pertama, Imitasi. Merupakan dorongan untuk meniru prilaku figur otoritas di lingkungan keluarga, misalnya orang tua, saudara, dan kerabatnya yang sering berinteraksi dalam sehari-hari. Kedua, Sugesti. Pemberian pengaruh kepada dirinya dan orang lain tentang suatu pendapat yang diterima secara sadar maupun tidak sadar tanpa reserve atau tanpa kritik, lebih cendrung karena alasan psikis. Ketiga, Identifikasi. identifikasi terjadi di luar lingkungan keluarga atas dorongan kecendrungan seseorang untuk 'menjadi sama' dengan sang Idola karena kedudukan sosialnya. Tidak penting sang idola tersebut dikenal langsung maupun tidak langsung. Biasanya, sang Idola merupakan figur otoritas dalam dunia yang digelutinya. Keempat, Simpati. Rasa simpati merupakan proses kejiwaan individual yang mengalami ketertarikan kepada seseorang/kelompok orang karena sikap, penampilan, wibawa, atau

${ }^{37}$ Mien Ahmad Rifai, Manusia Madura..., 45 
perbuatannya. Adapun prinsip-prinsip hidup Blatēr, antara lain; ketauhidan, hormat kepada Embho' (Ibu), hormat kepada Ghuru (Guru), ajhegeh téngka (menjaga etika), dan ajhegeh harga diri. Dari lima prinsip ini, empat diantaranya yaitu ketauhidan, hormat kepada Embho' (Ibu), hormat kepada Ghuru (Guru), dan ajhegeh téngka (menjaga etika), ada pembenarannya dalam Al-Qur'an maupun Al-Hadits. Sedangkan ajhegeh harga diri dengan menjadikan carok sebagai cara mengembalikan harga diri yang terlecehkan, jika demikian motif dan tujuannya, sama sekali tidak ditemukan pembenaran dalam ajaran agama Islam.

\section{Daftar Pustakan}

Abraham H Maslow, Motivation and personality, (USA: Harper and Row Publication, 1970)

Abu Ahmadi, Psikologi Sosial, (Semarang: Rineka Cipta, 2007)

Abdur Rozaki, Islam, Oligarki Politik, dan Perlawanan Sosial, (Yogyakarta: SUKA Press, 2016)

Budi Hardiman, Seni Memahami: Hermeneutik dan Schleiermacher sampai Derrida, (Yogyakarta: Kanisius, 2015)

Latief Wiyata, Carok; Konflik Kekerasaan dan Harga Diri Orang Madura, (Yogyakarta: LKIS, 2002)

Madura yang Patuh?; Kajian Antropologi Mengenai Budaya Madura, (Jakarta: CERIC-FISIP UI, 2003)

Muniri, Titik Temu Pandangan Hidup Kalangan Blatĕr dan Pemikiran Murjiah. Jurnal Al-Fikrah. 2020

-------, Fatwa MUI dan Implikasinya Terhadap Hubungan Agama Negara; Studi Power/Knowledge Michel Foucault Atas Fatwa MUI Tentang Pluralisme, Liberalisme, dan Sekulerisme Agama. Skripsi. Fak. Syariah, Jurusan Siyasah Jinayah, IAIN Sunan Ampel Surabaya, 2008. 
-------, KH. Asy'ari Umar; Ulama Mandiri Pengokoh Tradisi, (Surabaya: Imtiyas, 2012), 16-18

M. Budyatna dan Leila MG, Teori Komunikasi Antar Pribadi, (Jakarta: Kencana, 2011)

Moeslim Abdurrahman Wahid, Islam sebagai Kritik Sosial, (Jakarta: Erlanga, 2003)

Muhammad Ibn Alawi Al-Maliki, Mafahim Yajibu 'an Tusahha, (Dubai: Dairah al-Awqaf wa al-Shu'un al-Islamiyyah, 1995)

Mien Ahmad Rifai, Manusia Madura; Pembawaan, Perilaku, Etos Kerja, Penampilan, dan Pandangan Hidupnya seperti Dicitrakan Peribahasanya,(Yogyakarta, Pilar Media, 2007)

Modul Pendidikan Kedamaian Berbasis Pesantren Tahun 2006 di Hotel Madinah Pamekasan.

https://id.wikipedia.org/wiki/Simpati, mengutip dari Tear, J; Michalska, KJ (2010). "Neurodevelopmental changes in the circuits underlying empathy and sympathy from childhood to adulthood". Developmental Science. 13 (6)

https://blog.bhiruhdheun.com/aneka-pribahasa-madura-etoskerja-dan-hubungan-sosial/

Ridwan Ahmad Sukri, Konsep Bapa', Babu, Guru, Rato pada Masyarakat Madura Sebagai Wujud Pengamalan Sila ke-2 Pancasila, Jurnal Filsafat, edisi ke-30. Oktober 1999.

Soerjono Soekanto, Sosiologi Suatu Pengantar, (Jakarta: Rajawali Pers, 2012)

Wahbah Zuhaily, Tafsir al-Munir fi al-Aqidah wa as-Syari'ah wa alManhaj, Jilid I (Damsik: Dar Al-Fikr, 2009)

Refensi dari Al-Qur'an dan Al-Hadits:

- QS. Al-Isra: 23

- QS. Al Isra: 33 
- HR. Anas bin Malik

- HR. Bukhari

- HR. Al-Bazzar

- HR. Bukhari-Muslim

- HR. Imam Muslim.

- HR. Abu Daud 